\title{
A new concept for the Paleogene lithostratigraphy in the onshore part of the Dolna Kamchiya Basin (eastern Bulgaria) on the basis of 3D modeling
}

\author{
Boris Valchev ${ }^{1}$, Hristo Dimitrov ${ }^{1}$, Dimitar Sachkov ${ }^{1}$ Sava Juranov² \\ ${ }^{1}$ University of Mining and Geology "St Ivan Rilski”, Department of Geology and Geoinformatics, 1 Prof. Boyan Kamenov Str., \\ Studentski Grad,1700 Sofia, Bulgaria; e-mails: b_valchev@mgu.bg; hristo_dimitrov@mgu.bg; dimitarsachkov@gmail.com \\ ${ }^{2}$ Sofia University "St Kliment Ohridski”, Department of Geology, Palaeontology and Fossil Fuels, 15 Tsar Osvoboditel Blvd, \\ 1504 Sofia, Bulgaria, e-mail: juranov@gea.uni-sofia.bg
}

(Accepted in revised form: August, 2020)

\begin{abstract}
This study is based on primary lithological data from 96 boreholes and lithostratigraphic interpretation of 17 seismic profiles from the onshore part of the Dolna Kamchiya Basin, which belongs to the onshore sector of the Moesian Platform and comprises the south-easternmost part of the Southern platform zone. Nine formal Paleogene lithostratigraphic units were recognized (the Byala, Komarevo, Dvoynitsa, Beloslav, Dikilitash, Aladan, Avren formations, the Dolni Chiflik Member of the Avren Formation, and the Ruslar Formation). For visualization of their spatial relationships and revealing the deep structure of the basin, a 3D lithological model was created. In addition, new data on the lithology, thicknesses and ages of the units were provided.
\end{abstract}

Valchev, B., Dimitrov, H., Sachkov, D., Juranov, S. 2020. A new concept for the Paleogene lithostratigraphy in the onshore part of the Dolna Kamchiya Basin (eastern Bulgaria) on the basis of 3D modeling. Geologica Balcanica 49 (2), 59-73.

Keywords: Paleogene, lithostratigraphy, 3D model, Dolna Kamchiya Basin, eastern Bulgaria.

\section{INTRODUCTION AND GEOLOGICAL SETTING}

The Dolna Kamchiya Basin is of great interest for the oil and gas prospecting in Bulgaria. More than 100 onshore boreholes have been drilled on a small area of about $300 \mathrm{~km}^{2}$ since the beginning of the 1950s. The basin, also known as the Dolna Kamchiya depression (Bokov et al., 1987) or Dolna Kamchiya sub-basin (Georgiev, 2012), comprises a small onshore area in the central Bulgarian Black Sea coast (Fig. 1) and extends offshore to the southeast into the Western Black Sea Basin. It occupies the south-easternmost part of the Southern platform zone of the Moesian Platform according to the division of Dabovski and Zagorchev (2009) (Fig. 1a) and is also known as the Southmoesian periplatform zone according to Bokov et al. (1987) (Fig. 1b). A brief review of the geological setting was published by Dimitrov and Georgiev (2005) and Stefanov (2018).

The present article aims at elucidating the spatial distribution and relationships of the Paleogene lithostratigraphic units in the onshore part of the Dolna Kamchiya Basin on the basis of lithostratigraphic interpretation of borehole lithologic logs and seismic profiles, and thus to clarify the deep geological structure of this sector of the territory of eastern Bulgaria.

\section{MATERIAL AND METHODS}

This investigation is based on integration of the primary lithological data from 96 onshore borehole sections (derived from the geological reports 
kept at the National Geological Fund, Ministry of Energy of the Republic of Bulgaria) and 17 unpublished seismic profiles (also kept at the National Geological Fund), which were lithostratigraphi- cally interpreted here. The borehole sections are unevenly distributed across the studied area. They were drilled and studied from the early 1950s to the middle 1990s for oil and gas prospecting and
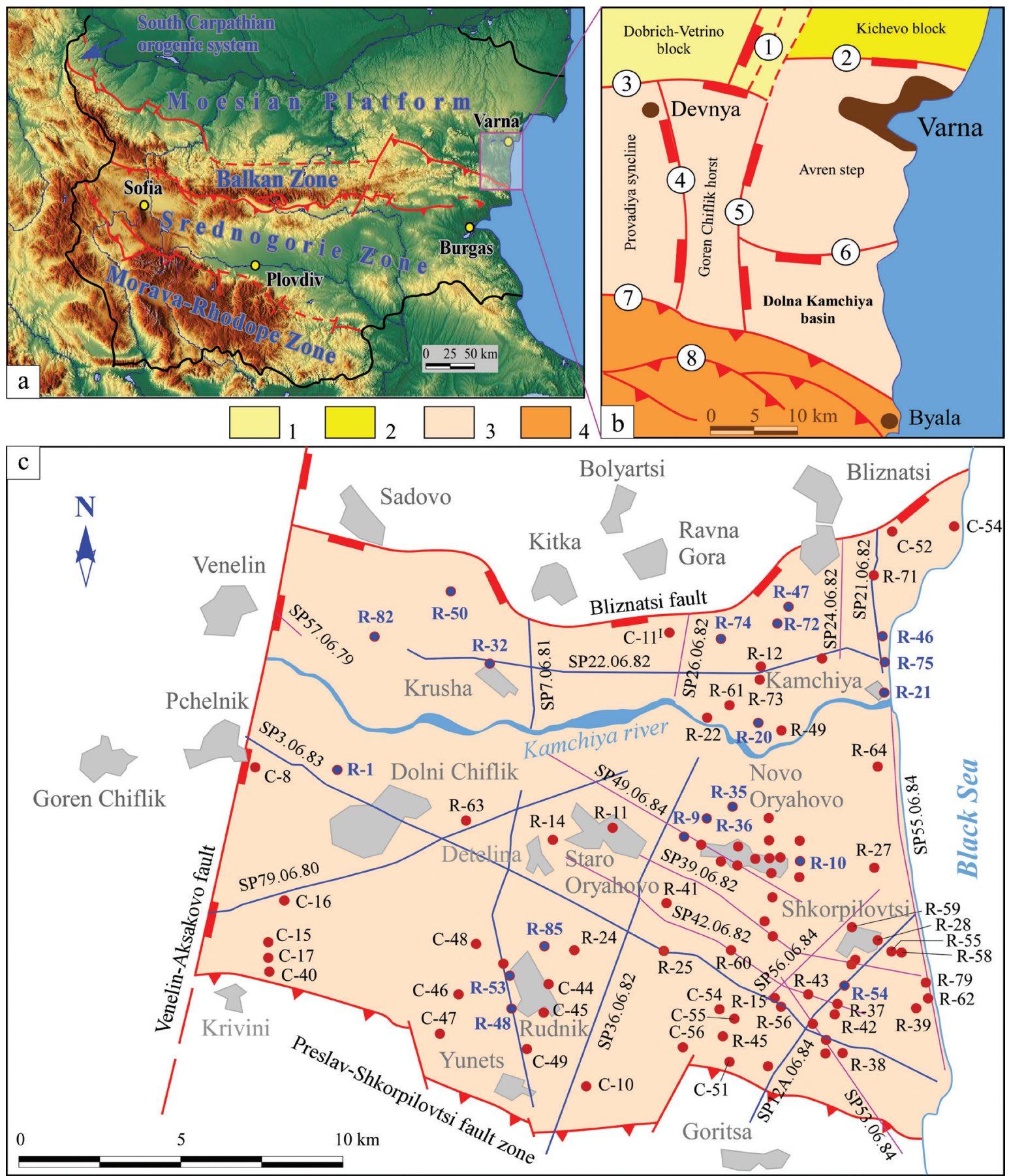

Fig. 1. a) Tectonic subdivision of the territory of Bulgaria (after Dabovski and Zagorchev, 2009) with location of the study area; b) Tectonic subdivision of the coastal part of central eastern Bulgaria (after Bokov et al., 1987, modified): 1 - North Bulgarian Arch; 2 - Varna monocline; 3 - South Moesian periplatform zone; 4 - Eastern Balkanides; faults: 1 - Dobrich-Venelin zone; 2 - Kichevo; 3 - Resen-Medovina; 4 - Kubrat-Vetrino; 5 - Venelin-Aksakovo; 6 - Bliznatsi; 7 - Preslav-Shkorpilovtsi zone; 8 - East Balkans frontal thrust; c) Simplified sketch map of the Dolna Kamchiya Basin with location of the wells and seismic profiles studied (the lithological logs of the boreholes, marked in blue, are shown in Figs 3, 4 and the lithostratigraphic interpretation of the seismic profiles, also marked in blue, are represented in Figs 5, 6). 
concern the following areas: Bliznatsi (Nikolova, 1983), Ravna Gora (Nikolova, 1985), Krusha (Nikolova, 1992), Dolni Chiflik (Baev and Vavilova, 1974; Vavilova, 1990), Samotino (Nikolova, 1968a, 1972; Dimitrova, 1991), Rudnik (Nikolova, 1968b), Dolna Kamchiya (Petuhov et al., 1952; Monov, 1971; Efremochkin et al., 1974; Vavilova et al., 1978; Nikolova, 1986), and Novo Oryahovo (Kocheva and Manchev, 1995).

The preparation of the 3D model database included defining of individual lithostratigraphic bodies after interpretation of the borehole lithologic logs and the seismic profiles (Fig. 1c). The generating of the 3D voxel lithological model was performed by means of software processing by Datamine Discover, based on the following steps: (i) software dividing into individual voxels with size $25 \times 25 \times 10 \mathrm{~m}$; (ii) statistical processing performed by discretized gridding method that uses Inverse Distance Weighting to interpolate discrete or classified data; (iii) to avoid errors caused by variability of thickness or the presence of gaps in individual boreholes, the radius of searching was chosen to be not more than 1 $\mathrm{km}$; and (iv) because of the vertical size of each voxel, bodies with thickness less than $10 \mathrm{~m}$ were excluded from the model.

\section{LITHOSTRATIGRAPHIC UNITS}

On the basis of the primary lithological data from the geological reports, we identified nine formal lithostratigraphic units in the Paleogene succession of the studied region, which are as follows: the Byala Formation; the Komarevo Formation; the Dvoynitsa Formation; the Beloslav Formation; the Dikilitash Formation; the Aladan Formation; the Avren Formation; the Dolni Chiflik Member of the Avren Formation; and the Ruslar Formation. The lithostratigraphic units demonstrate varieties in their spatial distributions and relationships throughout the studied area. Valchev et al. (2018a, 2019) discussed the nomenclature, definition and stratigraphic background of the Komarevo, Beloslav, Dikilitash, Aladan, Avren, and Ruslar formations. Therefore, only a brief description of each of these units is given bellow. It should be noted that the Paleogene succession crops out as a narrow strip with NW-SE direction in the southernmost area of the Dolna Kamchiya Basin (Fig. 2). Herein, another unit, the Arnautlar Formation (Priabonian), also occur, but it has not been penetrated, and therefore has not been taken into consideration in the present study.

\section{Byala Formation}

The unit was first described by Zlatarski (1907) as "whitish limy marls". Later on, Bontchev (1926) named the rocks "Byala clayey marls". Juranov (1984) at first united them into the "limestone-marl unit", and then formalized the unit as the "Byala Limestone-Marl Formation” (Juranov, 1991; see also Juranov, 1993a). Initially, the rocks were referred to the North-European type of the Upper Cretaceous in Bulgaria (Gočev, 1932; Cohen, 1938; Botev, 1953), but since the beginning of the 1960s, they have been considered to belong to the Medi-

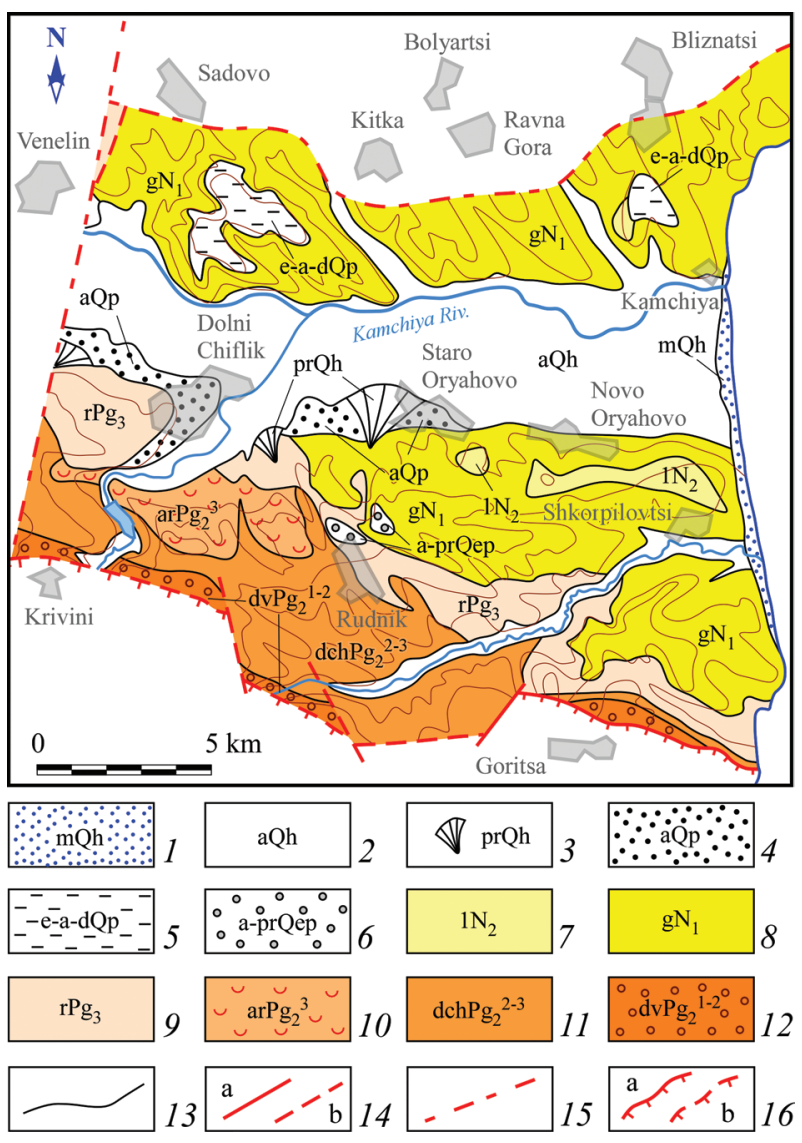

Fig. 2. Geological map of the Dolna Kamchiya Basin (after Cheshitev et al., 1991; Kančev and Gerčeva, 1992, modified). Legend: 1 - recent marine beach sands (Holocene); 2 - alluvial deposits of river bed and flood plain (Holocene); 3 - proluvial deposits (Holocene); 4 - alluvial deposits of $1^{\text {st }}$ and $2^{\text {nd }}$ terraces above flood plain (Pleistocene); 5 - eolian-alluvial-talus deposits (Pleistocene); 6 - alluvial-proluvial deposits (Eopleistocene); 7 - undivided Pliocene sediments; 8 - Galata Fm. (Miocene); 9 - Ruslar Fm. (Oligocene); 10 - Arnautlar Fm. (Priabonian); 11 - Dolni Chiflik Mb. of the Avren Fm. (Bartonian-Priabonian); 12 - Dvoynitsa Fm. (Ypresian-Lutetian); 13 - lithostratigraphic boundary; 14 - normal fault (a - certain, b - uncertain); 15 - fossilized normal fault; 16 - trust (a - certain, b - uncertain). 
terranean type (Trifonova, 1960; Atanassoff, 1961; Sinnyovsky, 2007; Dabovski et al., 2009). In the Eastern Balkanides, the Byala Formation, cropping out at the sea coast around the town of Byala, is well investigated from paleontological (calcareous nannofossils, ammonites, echinoids, inoceramids, and partly small foraminifera) and stratigraphical (lithostratigraphy, biostratigraphy, chronostratigraphy, cyclic and event stratigraphy, magnetostratigraphy) points of view (e.g., Preisinger et al., 1993a, b; Peybernès et al., 2003). Detailed reviews of the geological investigations on the unit were given by Sinnyovsky (2006) and Dabovski et al. (2009). In the Dolna Kamchiya Basin, the formation occurs in its south-easternmost part only, being represented by a succession of gray thin-bedded marls passing into marly limestones up-section. The lowermost levels are occupied by gray sandy limestones with calcite veins.

On the basis of calcareous nannoplankton (Ivanov and Stoykova, 1994; Sinnyovsky, 2001, 2006; Stoykova and Ivanov, 2006a, b) and planktonic foraminifera (Juranov, 1983; Valchev, 2017), the total chronostratigraphical range of the unit in the eastern Balkanides was determined as lower Campanianupper Thanetian. In the Dolna Kamchiya Basin, the chronostratigraphical range has been determined as Maastrichtian-Danian based on scarce remains of planktonic foraminifera (Juranov, unpublished data). The recorded thickness of the unit varies between $51 \mathrm{~m}$ and $88 \mathrm{~m}$, but it should be noted that the lower boundary was not penetrated. The upper boundary of the unit is an unconformity with the Dvoynitsa Formation (Gebesh Member).

\section{Komarevo Formation}

It comprises gray to dark gray thin-bedded organogenic, sandy and clayey limestones with gradual lateral transitions between them. Rare chert nodules and glauconite grains occupying predominantly the lower levels were also recorded. The fossil remains include mainly detritic lithothamnium algae, as well as small and large foraminifera, calcareous nannofossils, and crinoids. The chronostratigraphical range of the unit in the studied area has been determined as Thanetian based on planktonic foraminifera (Juranov, unpublished data). The thickness of the Komarevo Formation is $40-75 \mathrm{~m}$, rarely up to 376 m (R-72 Dolen Bliznak borehole), increasing from the west to the east and southeast. The unit overlies different levels of the Upper Cretaceous (usually the Mezdra Formation, introduced by Yolkichev, 1986), as the boundary is an unconformity. The upper boundary is a sharp lithological contact or unconformity with different units of the Paleogene section (Dvoynitsa Formation, Beloslav or Dikilitash Formation, Aladan Formation).

\section{Dvoynitsa Formation}

The unit was formally introduced by Juranov and Pimpirev (1989) in the coastal region of the Eastern Balkanides between the towns of Byala and Obzor. Later on, Vangelov and Sinnyovsky (2011) summarized all available data on the lithology, distribution and chronostratigraphical range of the formation, and proved that it is largely distributed in the Eastern Balkanides. The Dvoynitsa Formation is composed of highly variable lithological types demonstrated in both the vertical and lateral distribution. Vangelov and Sinnyovsky (2011) motivated the definition of three members of the Dvoynitsa Formation (the Armera, Gebesh, and Goritsa members), noting that there is no section containing the entire formation's lithological types, and clarified the statute of names such as "St Atanas Member”, "Meshelika Member”, “Kozichino Series", "Goritsa Formation" concerning different parts of the unit. Generally, it is composed of medium- to coarse-grained thick-bedded sandstones, alternating with thin-bedded fine-grained sandstones, siltstones, marls, sandy clays and conglomerate.

Recently, we established that, in the Dolna Kamchiya Basin, the Dvoynitsa Formation is composed of four lithological types (Valchev et al., 2018b): (i) clast- to matrix-supported conglomerates (sandy and clayey debrites); (ii) thick-bedded sandstones; (iii) rhythmic alternation of thin-bedded sandstones, marls and shales (thin-rhythmic turbidites); and (iv) brown-reddish and greenish clays and marls with thin interbeds of fine-grained sandstones. The former two lithological types were referred to the Armera Member, the third one to the Gebesh Member, and the latter one to the Goritsa Member. On the basis of planktonic foraminiferal data, we determined the chronostratigraphical range of the Dvoynitsa Formation as lower Ypresian-middle Lutetian (Valchev et al., 2018b). In the Eastern Balkanides, the unit ranges from the uppermost Maastrichtian to the middle Lutetian (Vangelov and Sinnyovsky, 2011).

Generally, the total thickness of the Dvoynitsa Formation in the Dolna Kamchiya Basin increases to the east and southeast. It varies from $24 \mathrm{~m}$ in the Staro Oryahovo area (R-14 St Ivan) to over $1500 \mathrm{~m}$ in the Rudnik and Samotino areas. It is worth emphasizing that calculation of the true thickness is usually impossible because of the tectonically 
complicated structure of the southern board of the Dolna Kamchiya Basin. Therefore, the data used in this study represent the apparent thicknesses. The Dvoynitsa Formation covers various types of limestones. In the majority of sections, they belong to the Upper Cretaceous (usually the Mezdra Formation) and the boundary is an unconformity. In a few sections, the Byala Formation (R-10 Novo Oryahovo borehole) or the Komarevo Formation (R-9 Staro Oryahovo borehole) was recognized, as the boundary is an unconformity or a sharp lithological contact. The upper boundary of the Dvoynitsa Formation is an unconformity with the Dolni Chiflik Member of the Avren Formation. Only one section (R-1 Georgi Traykov borehole) reveals that the contact is with the typical Avren Formation.

\section{Beloslav and Dikilitash formations}

In the Dolna Kamchiya Basin, we examined these units together because of their similar lithology (loose terrigenous successions) and the indistinct boundary between them. This lithobody consists of gray fine-grained loose sandstones to sands, limy at the upper levels and composed predominantly of quartz grains at the lower levels. They contain bivalve detrite and remains from large foraminifera. In some cases, the sandstones pass into dark gray sandy limestones at the lowermost part of the unit. Based on nummulitids, the chronostratigraphical range of both formations was determined as Ypresian (Aladjova-Khrischeva, 1984). The thickness varies from $5 \mathrm{~m}$ (R-78 Bliznatsi borehole) to $55 \mathrm{~m}$ (R-32 Krusha borehole). The lower boundary is a sharp lithologic contact or unconformity with the Komarevo Formation, or an unconformity with the Upper Cretaceous limestones (R-20 Poda borehole). The upper boundary is a sharp lithological contact with either the Aladan or Avren Formation.

\section{Aladan Formation}

The unit comprises gray detritic and micritic limestones with numerous glauconite grains. Detrite includes mainly remains from both large and small foraminifera. Rare ostracod shells were also recorded. On the basis of nummulitids, the chronostratigraphical range of the Aladan Formation was determined as Ypresian (Aladjova-Khrischeva, 1984). Its thickness varies from $4 \mathrm{~m}$ (R-50 Krusha borehole) to 47 m (R-74 Kamchiya borehole). The lower boundary is a sharp contact or a fast gradual transition with the Dikilitash or Beloslav formations. The upper boundary with the Avren Formation is a sharp lithological contact.

\section{Avren Formation}

It is composed of pale gray to gray-greenish thinbedded marls with interbeds of siliciclastic hyporocks: calcareous-clayey hyposilts, silty hypoclays, silty marls, clayey sandstones, sandy limestones, and calcareous gravels. The latter are the dominating lithologic types south of the Kamchiya River. This fact allowed previous investigators to define the Dolni Chiflik Member of the Avren Formation (see Juranov, 1993b).

The typical Avren Formation, composed of the above-mentioned marls, was recorded in the northern board of the Dolna Kamchiya Basin only (north of the Kamchiya River). Locally, the marls are interbedded with thin-bedded sandy marls or dark gray clays. Sporadic beds of clayey limestones were recorded at the base of the unit. Planktonic foraminifera indicate that the chronostratigraphical range of the Avren Formation in the basin is Lutetian-Priabonian (see Juranov, 1993b). Its thickness varies from $170 \mathrm{~m}$ (R-21 Kamchiya borehole) to $388 \mathrm{~m}$ (R-72 Dolen Bliznak borehole). It should be noted that, in some areas, the lower boundary has not been penetrated, and therefore it is not possible to calculate the exact total thickness. The lower boundary is a sharp lithological contact with either the Aladan or the Dikilitash Formation. The upper boundary is a sharp lithological contact or an unconformity with the Ruslar Formation.

\section{Dolni Chiflik Member of the Avren Formation}

It was first described as "Dolen Chiflik Series" (Pollak, 1933) and later formalized as the Dolni Chiflik Member (Juranov, 1993b). The unit was also known as "marl-sandy complex" (Efremochkin et al., 1974; Vavilova et al., 1978). Aladjova-Khrischeva (1991, Fig. 10) referred the rocks to the Avren Formation, while Cheshitev et al. (1994) and Kančev (1995) considered this body as the "Dolni Chiflik Formation". The unit consists largely of siliciclastic hyporocks: calcareous-clayey hyposilts, silty hypoclays, silty marls, clayey sandstones, sandy limestones, and calcareous gravels. They form alternation of packages of sandy marls and clayey sandstones, the latter dominating. The unit was recorded in the southern board of the Dolna Kamchiya Basin only (south of the Kamchiya River). On the basis of planktonic foraminifera, the age was determined as Bartonian-Priabonian (Juranov, unpublished data). Its thickness increases gradually to the south and east, varying from $409 \mathrm{~m}$ (R-48 Rudnik borehole) to 1195 m (R-33 Novo Oryahovo borehole). The lower boundary is an unconformity with the Dvoynitsa 
Formation. The upper boundary is a sharp lithological contact with the Ruslar Formation.

\section{Ruslar Formation}

The unit is composed of dark gray to brownish or black thin-bedded non-calcareous clays interbedded with thin-bedded fine-grained clayey, loose sandstones. Rare biotite or muscovite flakes, squames of fish, plant remains, as well as numerous spicules of silica sponges were recorded. At some levels, thin-bedded marls occur. The chronostratigraphical range of the formation was determined on the basis of rare planktonic foraminiferal remains as Oligocene (Juranov, unpublished data). The thickness varies from $91 \mathrm{~m}$ (R-37 Samotino borehole) to $910 \mathrm{~m}$ (R-64 Poda borehole). Generally, it increases to the east. The lower boundary is a sharp lithological contact with the Dolni Chiflik Member of the Avren Formation south of the Kamchiya River and with the typical Avren Formation north of the river. The upper boundary is an unconformity with the Neogene Galata Formation (introduced by Popov and Kojumdjieva, 1987).

\section{REGIONAL LITHOSTRATIGRAPHIC ASPECTS}

Examples of the distinguished lithostratigraphic successions in different localities are shown in Figs 3, 4 by illustration of 19 representative borehole sections, as well as in Figs 5, 6 presenting lithostratigraphic interpretation of eight seismic profiles. Generally, two lithostratigraphic successions were established. In the northern board of the Dolna Kamchiya Basin (north of the Kamchiya River), the Paleogene comprises the Komarevo, Beloslav, Dikilitash, Aladan, Avren, and Ruslar formations (Figs 3, 5). The most complete sections, including all six units, were recorded in the Krusha area (with the exception of a single borehole log - see Fig. $3 b, c$ ), as well as in the area close to the Kamchiya River mouth (Fig. 3h). The Komarevo Formation was recorded in the western and eastern parts of the area, as it is usually covered by the Beloslav or Dikilitash Formation (Fig. 3a, $c, e, h$ ). In a single section in the Kamchiya area, the Aladan Formation is a cover (Fig. 3i). On the other hand, the latter is usually missing, except in the Krusha area; it was recorded only in the easternmost part of the board (Fig. 3d, h. i). In the coastal part of the board, lateral changes in the lower levels of the Paleogene are observed; the northern sections are composed of the Beloslav and Dikilitash formations only (Fig. 3f). A specific feature can be seen in R-20 Poda borehole, where 4-m thick detritic nummulitic limestones occur amongst the terrigenous succession of the Beloslav and Dikilitash formations (Fig. 3g). The Avren and Ruslar formations are widespread in the entire northern board of the basin. Another characteristic feature of this part of the basin is that the Paleogene is covered by the Neogene sediments of the Galata Formation in the entire area of its distribution (Figs 3, 5).

The lithostratigraphic interpretation based on correlation with the interpreted closest borehole logs of the seismic profiles (Fig. 5) confirmed the data obtained from the borehole logs' interpretation. It should be noted that the resolution of the seismic record does not allow dividing lithologic bodies thinner than $30 \mathrm{~m}$, and therefore the Beloslav, Dikilitash, and Aladan formations are visualized as a unified body.

In the southern board of the Dolna Kamchiya Basin (south of the Kamchiya River), the Paleogene is represented by the Byala, Komarevo, Dvoynitsa formations, the Dolni Chiflik Member of the Avren Formation, and the Ruslar Formation (Figs 4, 6). The Byala Formation is limited in the south-eastern part of the area (Fig. 4c), as well as the Komarevo Formation (Fig. $4 b, h$ ). Possibly, there are lateral transitions between these two units, but the available data on their distribution do not allow a reliable interpretation. In the area of the town of Dolni Chiflik (formerly Georgi Traykov) and in the eastern part of the southern board, the sections include three units: the Dvoynitsa Formation, the Dolni Chiflik Member, and the Ruslar Formation (Fig. 4a, $c-e, h, i$ ), while the southwestern sections comprise the Dvoynitsa Formation and the Dolni Chiflik Member only (Fig. $4 f, g$ ). The Neogene cover exists in the northeastern half of the southern board of the basin. Thus, the Dvoynitsa Formation, the Dolni Chiflik Member, and the Ruslar Formation crop out in the southwestern half of the area. This fact was confirmed by the seismic profiles' interpretation (Fig. 6), which revealed also the complicated tectonic structure of the southern board of the Dolna Kamchiya Basin.

\section{D MODELING OF PALEOGENE LITHOSTRATIGRAPHY}

To generate a 3D model, individual sets of lithostratigraphic bodies were established. They include base, cover, and eight bodies of Paleogene lithostratigraphic units (Fig. 7).

\section{Base}

The base comprises different lithostratigraphic units of Early and Late Cretaceous age. For the purpose 
of the 3D modeling, they have not been referred to any specific lithostratigraphic units and have been visualized as two unified bodies (Fig. 8a). The Up- per Cretaceous base is widespread in the whole studied area. The "gaps" in the model are due to the fact that the base was not penetrated in some areas.



R-46 Kamchiya

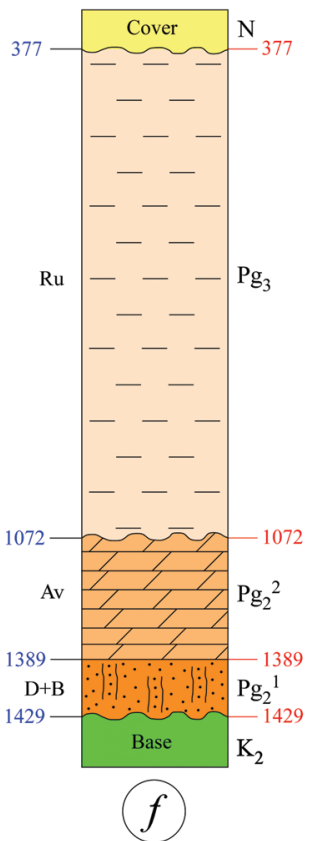

R-32 Krusha

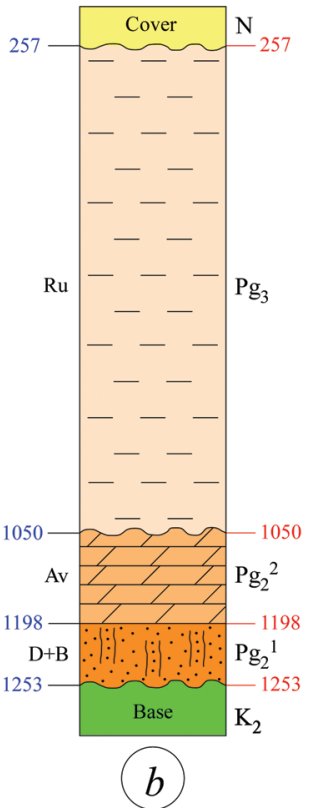

R-20 Kamchiya (Poda)

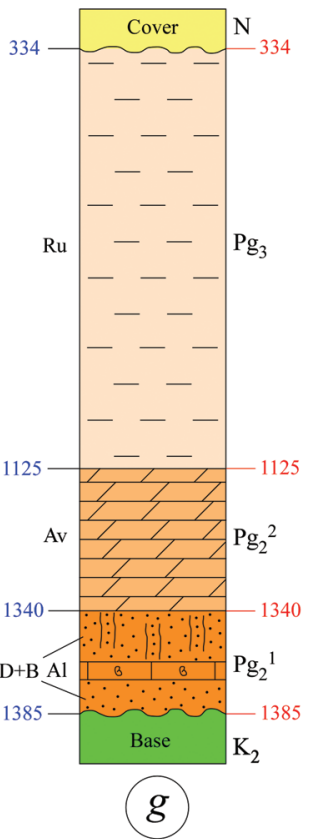

R-50 Krusha

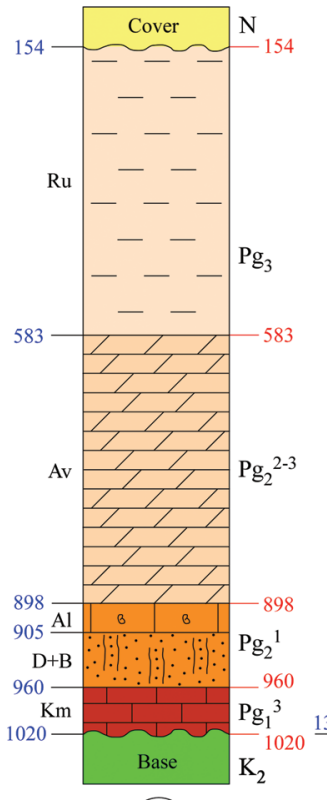

(c)

R-21 Kamchiya

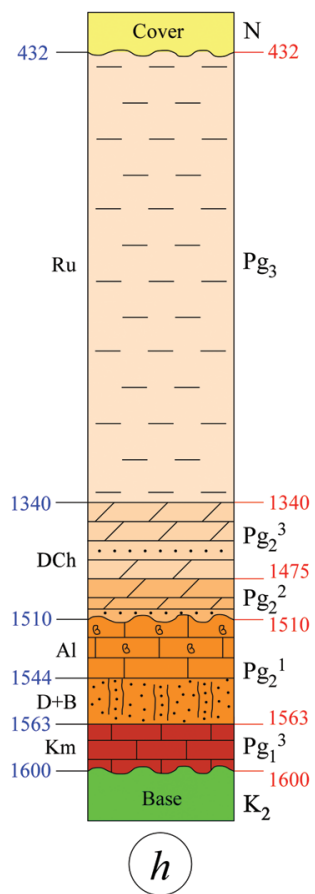

R-47 Dolen Bliznak

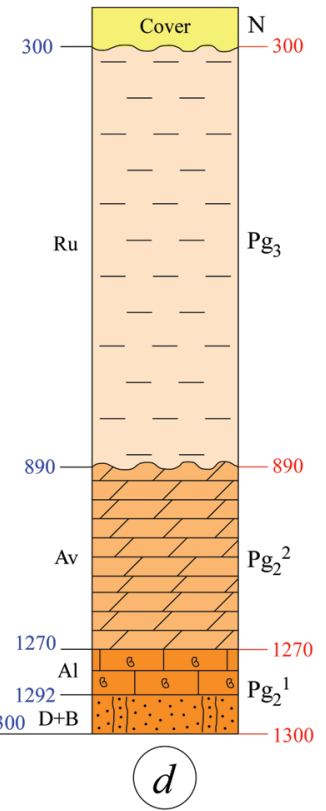

R-74 Kamchiya

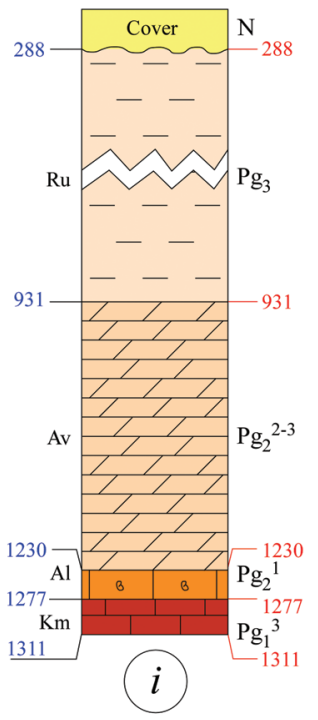

R-72 Dolen Bliznak

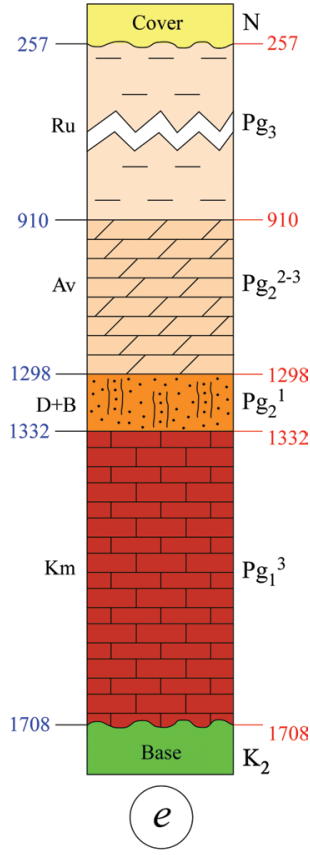

R-75 Kamchiya

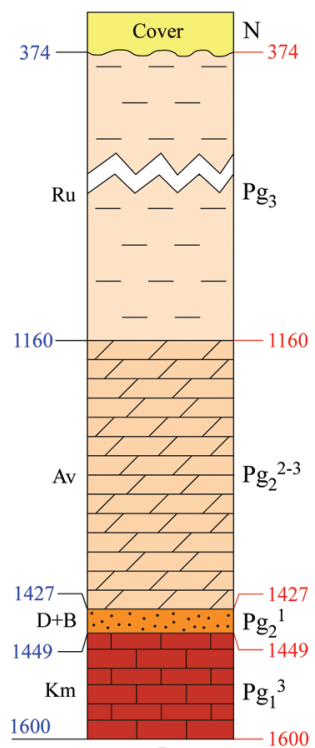

(j)

Fig. 3. Lithological logs of selected borehole sections from the northern board of the Dolna Kamchiya Basin as examples for the recorded lithostratigraphic successions: a) R-82 Krusha; b) R-32 Krusha; c) R-50 Krusha; d) R-47 Dolen Bliznak; e) R-72 Dolen Bliznak; f) R-46 Kamchiya; g) R-20 Kamchiya (Poda); h) R-21 Kamchiya; i) R-74 Kamchiya; j) R-75 Kamchiya. The chronostratigraphic subdivision is based on reinterpretation of biostratigraphic data from Shutskaya et al. (1972), as well as on unpublished planktonic foraminiferal data obtained during the present study by S. Juranov. Abbreviations: Km - Komarevo Fm.; B+D - Beloslav and Dikilitash fms; Al - Aladan Fm.; Av - Avren Fm.; DCh - Dolni Chiflik Mb.; Ru - Ruslar Fm. 


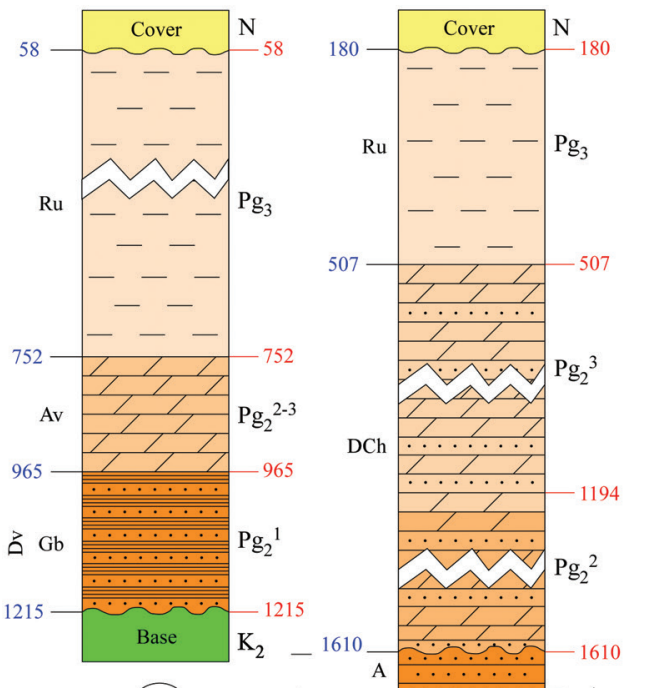

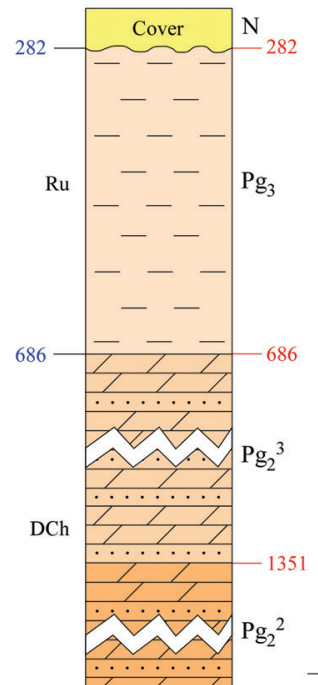

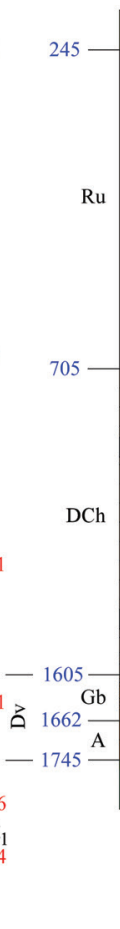

(b)

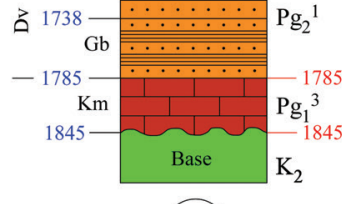

(c)

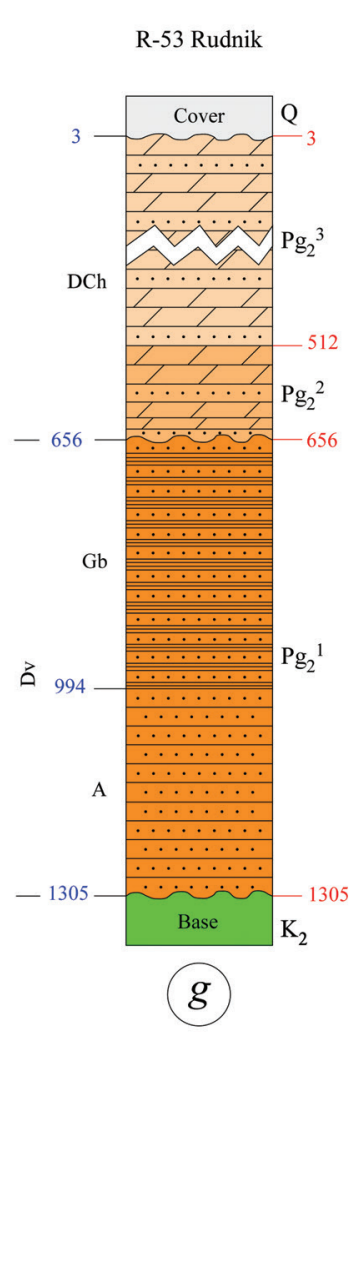



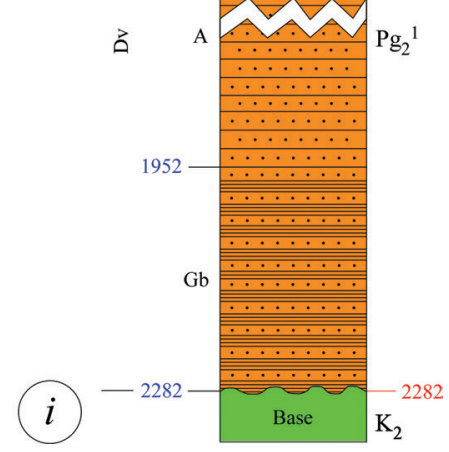


Fig. 4. Lithological logs of selected borehole sections from the southern board of the Dolna Kamchiya Basin as examples for the recorded lithostratigraphic successions: $a$ ) R-1 Georgi Traykov (Dolni Chiflik); $b$ ) R-9 Staro Oryahovo; $c$ ) R-10 Novo Oryahovo; d) R-35 Novo Oryahovo; e) R-36 Novo Oryahovo; f) R-48 Rudnik; g) R-53 Rudnik; $h$ ) R-85 Rudnik; i) R-54 Samotino. The chronostratigraphic subdivision is based on reinterpretation of biostratigraphic data from Shutskaya et al. (1972), as well as on unpublished planktonic foraminiferal data obtained during the present study by S. Juranov. Abbreviations: By - Byala Fm.; Km - Komarevo Fm.; Dv - Dvoynitsa Fm.; A - Armera Mb.; Gb - Gebesh Mb.; Go - Goritsa Mb.; Av - Avren Fm.; DCh - Dolni Chiflik Mb.; Ru - Ruslar Fm.

\section{Paleogene}

The varieties of the lithological features of some units and the characteristics of the lithostratigraphic boundaries led us to use different approaches during the 3D modeling. The Byala, Komarevo, Aladan, and Avren formations, the Dolni Chiflik Member of the Avren Formation, as well as the Ruslar Formation, are shown as separate bodies. They exhibit clear lithological features and sharp boundaries. The spatial relationships of the three members of the Dvoynitsa Formation were visualized by 3D lithologic model (Valchev et al., 2018b), and therefore in the present model the unit is represented as a unified body. The similar lithology (loose terrigenous successions) and the indistinct boundary between them forced us to merge the Beloslav and Dikilitash formations in one unified body.

The Byala Formation was established in two boreholes in the south-easternmost part of the study area (Fig. 8a). Despite the fact that the lower levels of the unit are Late Cretaceous in age, the entire formation's volume is included in the model.

In total, the Komarevo Formation was established in 11 borehole sections distributed mainly in four regions (Fig. 8a): Krusha, Bliznatsi-Kamchiya, Staro Oryahovo, and Rudnik.

The Dvoynitsa Formation was recorded in 56 borehole sections. It is widespread in the southern board of the Dolna Kamchiya Basin (Fig. 8b).

The Beloslav and Dikilitash formations were proved as a unified body in a total of 10 borehole sections. It is widely distributed in the northern board of the basin (Fig. 8b).

The Aladan Formation was established in five borehole sections in the eastern area of the northern board of the basin (Fig. 8b).

The Avren Formation was proved in 18 borehole sections located (with the exception of the R-1 Georgi Traykov borehole) in the northern board of the Dolna Kamchiya Basin (Fig. 8c), while the Dol- ni Chiflik Member was established in 69 borehole sections from the southern board of the basin.

The Ruslar Formation was recorded in 80 boreholes, as it is distributed in almost the entire studied area, except in its south-western part (Fig. 8d).

\section{Cover}

In the northern board, as well as in the eastern part of the southern board of the Dolna Kamchiya Basin, the Paleogene succession is covered by the Galata Formation (Fig. 7). The Quaternary deposits have not been taken into consideration in the present study.

\section{DISCUSSION}

The majority of the Paleogene lithostratigraphic units described in this article are wide spread in northeastern Bulgaria. Compared to the other studied areas (Dobrogea - Valchev et al., 2018a; the Varna Plateau - Valchev et al., 2019; the Avren Plateau - Valchev and Dimitrov, 2020), the Dolna Kamchiya Basin reveals some individual characteristic features. Here, the Komarevo Formation demonstrates similar lithology (including lateral transitions between the lithologic types), but thickness variations are greater than in the other studied areas. The Beloslav and Dikilitash formations show features (loose terrigenous rocks and indistinct boundary between them), which are similar to these observed in Dobrogea. This fact forced us to examine them together, while in the Varna Plateau and the Avren Step the two units were characterized as separate lithobodies.

The Aladan Formation is spatially restricted to the northeastern part of the Dolna Kamchiya Basin, but it demonstrates the same lithologic features as in the other three studied areas. The thickness variety of the unit is similar to that in Dobrogea. 


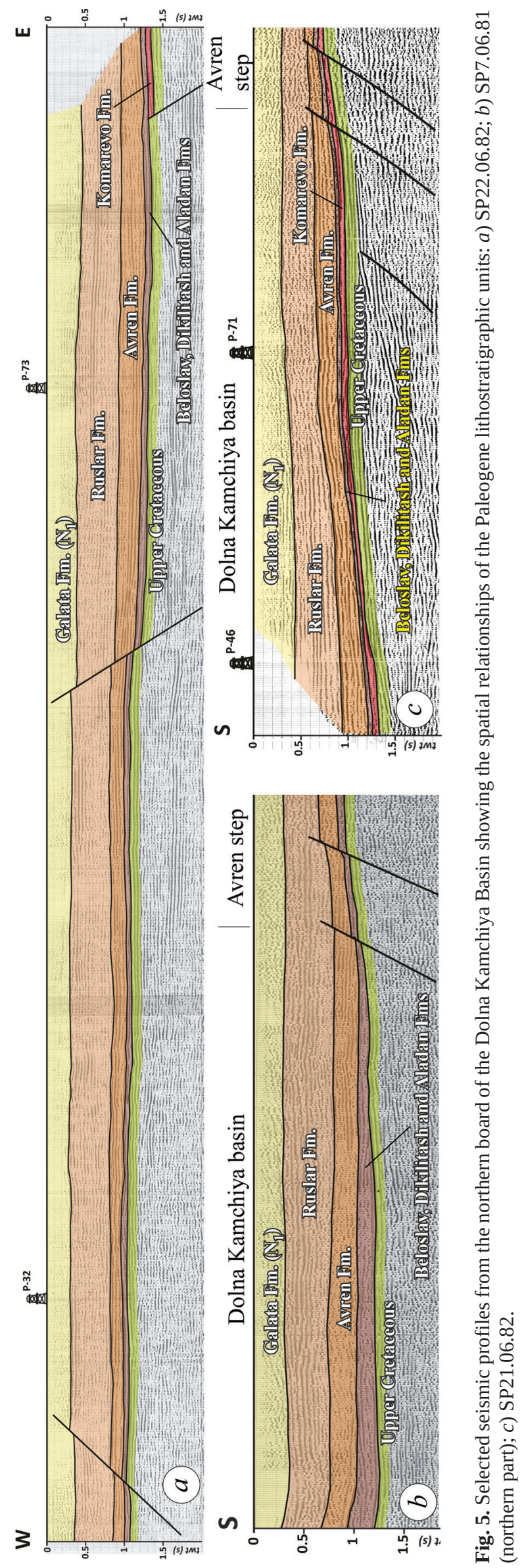



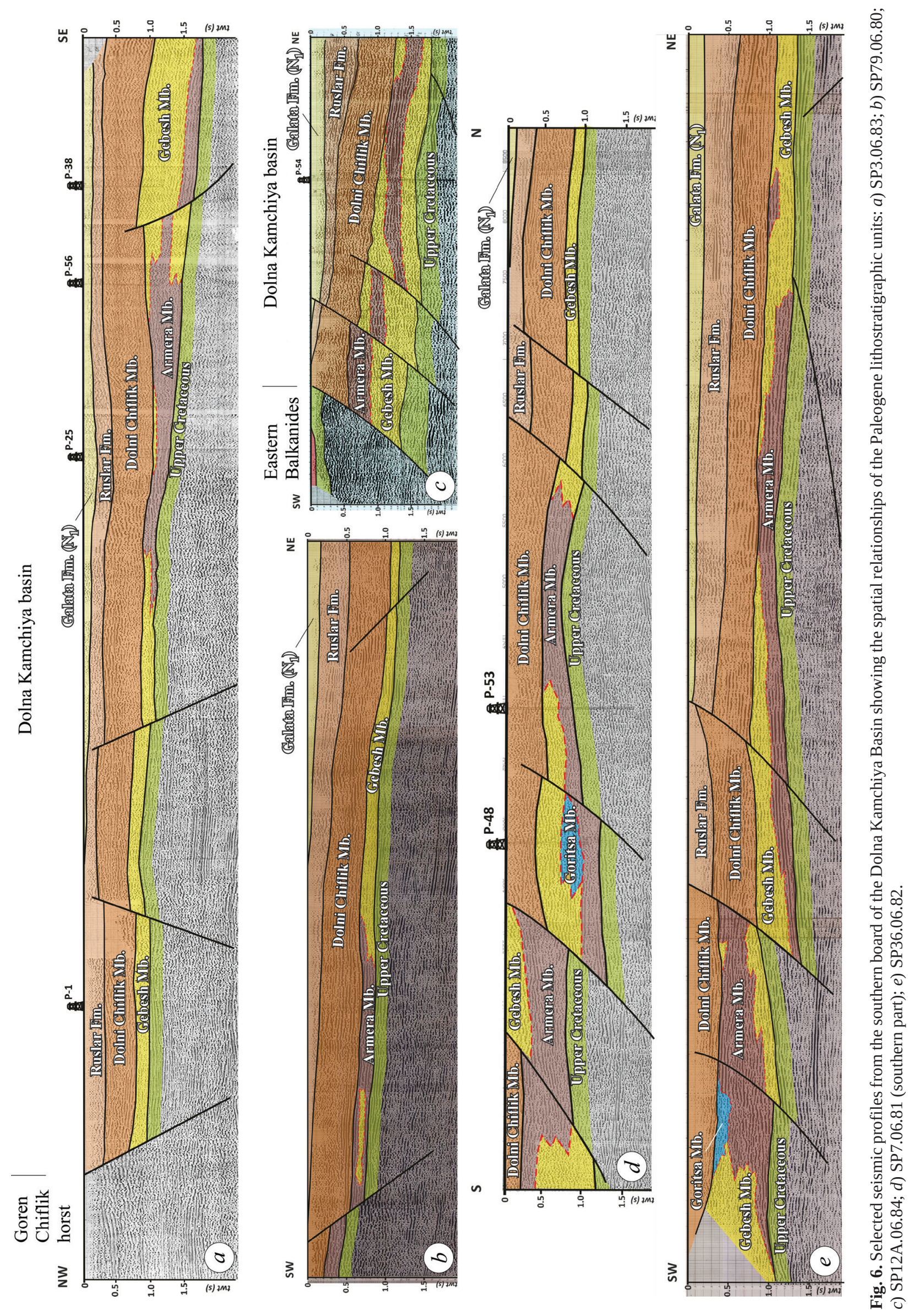


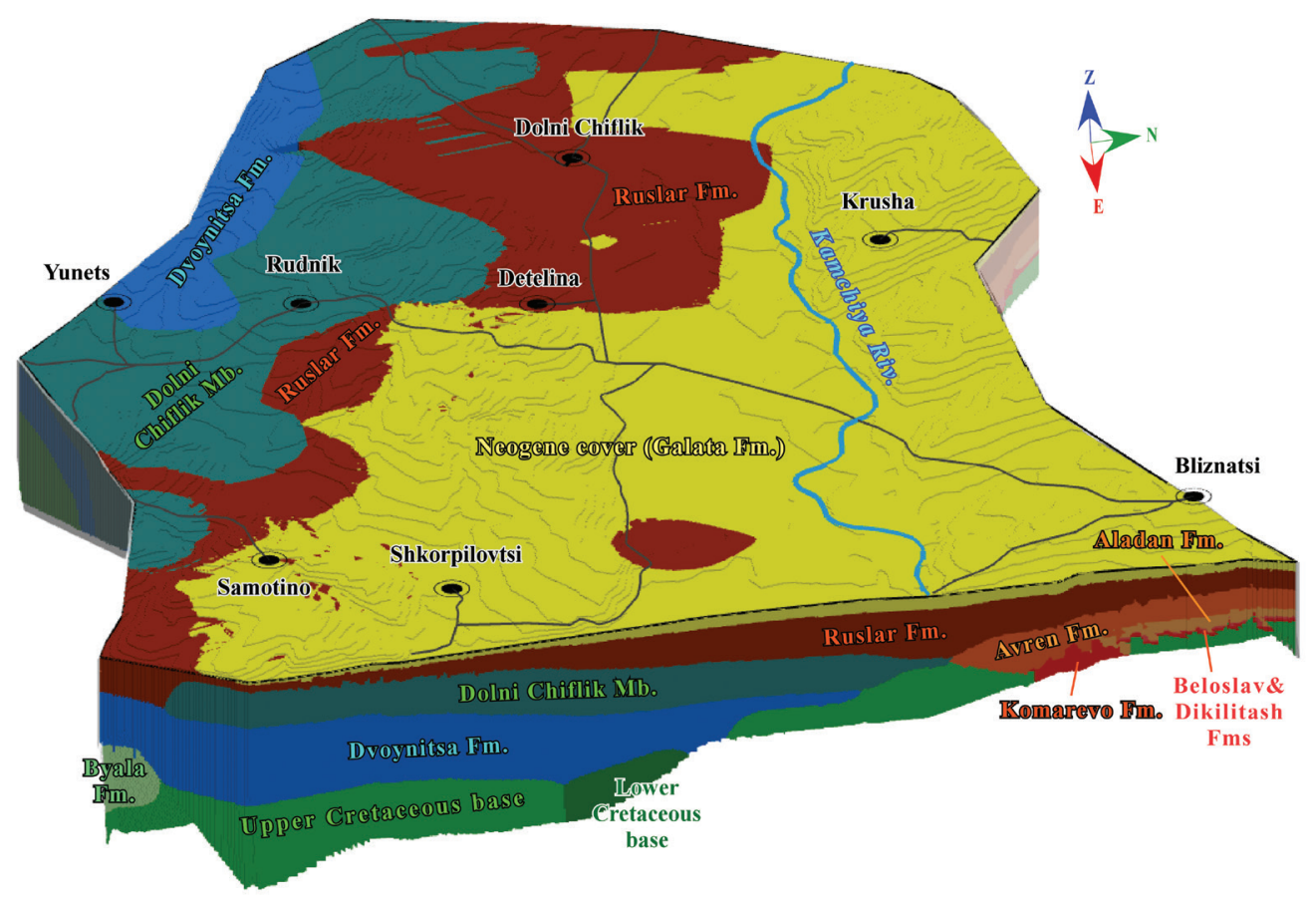

Fig. 7. 3D model of the Paleogene lithostratigraphic units.
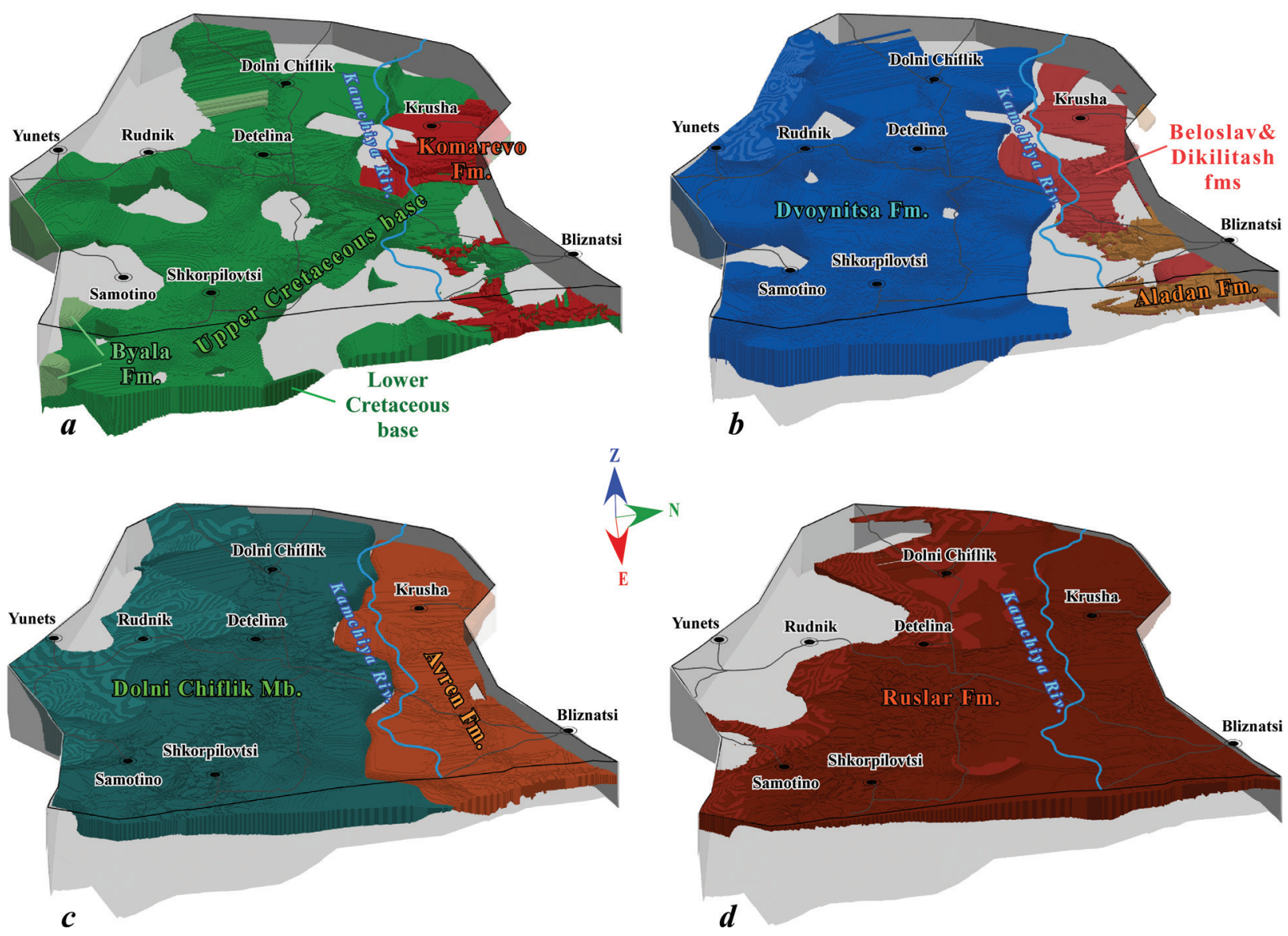

Fig. 8. 3D models of: $a$ ) the Lower and Upper Cretaceous base, the Byala and Komarevo fms; $b$ ) the Beloslav, Dikilitash, Aladan, and Dvoynitsa fms; c) the Avren Fm. and the Dolni Chiflik Mb.; d) the Ruslar Fm. 
In Dobrogea, the Varna Plateau, and especially in the Avren Step, the Avren Formation shows considerable lithologic diversity; three distinct packages were divided in the first two areas, while the third one revealed the presence of seven cases of lithologic successions. In the Dolna Kamchiya Basin, the unit was divided into two bodies (the typical Avren Formation and the Dolni Chiflik Member) demonstrating distinct lithologic features and comparatively homogeneous structure. The thickness of the unit increases sharply to the south.

The Ruslar Formation is characterized by comparatively homogeneous structure; the marly package, established in Dobrogea and the Varna Plateau, and the concentration of the sandy lithologic types at the base of the unit were not recorded in the Dolna Kamchiya Basin. Moreover, no manganese deposits were found here. Similar lithologic features were observed in the Avren Step.

\section{CONCLUSIONS}

The lithostratigraphic investigation of the Paleogene in the onshore sector of the Dolna Kamchiya Basin by means of borehole sections and seismic profiles confirmed the wide subsurface distribution of the Paleogene sedimentary successions across the whole investigated area. The presence of nine formal lithostratigraphic units, which have been previously described, was proven. New data on the age of the units were provided herein. The compiled database and the 3D lithologic model revealed new features concerning some regional aspects (lithology, thickness, spatial distribution and relationships) of the lithostratigraphic units. Thus, a reliable basis for further paleogeographic reconstructions was found.

\section{Acknowledgements}

The authors thank Dr Iskra Lakova and Dr Valeri Sachanski for detailed reviews with useful suggestions.

\section{REFERENCES}

Aladjova-Khrischeva, K. 1984. Stratigraphie des dépôts éocènes aux environs du village Beloslav, département de Varna. Review of the Bulgarian Geological Society 45 (1), 33-44 (in Bulgarian, with French abstract).

Aladjova-Chrisčeva, K. 1991. Stratigraphic subdivision and correlation of Paleogenic deposits in Northeast Bulgaria. Geologica Balcanica 21 (2), 12-38 (in Russian, with English abstract).

Atanassoff, A. 1961. Géologie du secteur maritime des Prébalkans et de la vallée de la Kamčia. Travaux sur la Géologie de Bulgarie, série Stratigraphie et Tectonique 2, 99-157 (in Bulgarian, with French abstract).

Baev, I., Vavilova, M. 1974. Report on the geological results from the deep prospecting drilling in Dolni Chiflik area conducted in 1972-1973. Ministry of Energy, National Geological Fund, report III-262, 178 pp. (in Bulgarian, unpublished).

Bokov, P., Georgiev, G., Monahov, I., Atanasov, A., Jelev, S., Dachev, Ch., Yordanova, D., Vavilova, M., Nikolova, M., Ognyanov, R. 1987. Tectonic framework. In: Bokov, P., Chemberski, Ch. (Eds), Geological premise for the oil-gas bearing of Northeast Bulgaria. Tehnika, Sofia, 109-119 (in Bulgarian).

Bontchev, G. 1926. Les roches dans les parties septentrionales du Balkan entre la mer Noire, le défilé de Kotel et les rivières Vrana et Goléma Kamtchia. Review of the Bulgarian Academy of Sciences 34 (16), 1-99 (in Bulgarian, with German abstract).

Botev, B. 1953. Sur la géologie de la partie la plus orientale de la Stara Planina de l'Est. Bulletin de l'Institut de Géologie près de l'Académie des Sciences de Bulgarie 2, 3-26 (in Bulgarian, with French abstract).

Cheshitev, G., Milanova, V., Popov, N., Kojumdgieva, E. 1991. Geological map of Bulgaria in scale 1:100 000. Varna and Resort Zlatni Pyasatsi Map Sheets. Committee of Geology and Mineral Resources, Department of Geophysical Prospecting and Geological Mapping.
Cheshitev, G., Milanova, V., Popov, N., Kojumdgieva, E. 1994. Explanatory note to the geological map of Bulgaria in scale 1:100 000. Varna and Zlatni Pyasatsi Map Sheets. Committee of Geology and Mineral Resources, Geology and Geophysics Ltd, Avers, Sofia, 75 pp. (in Bulgarian, with English abstract).

Cohen, E. 1938. Geologische Profilen durch den Östlichen Balkan mit besonderer Berücksichtigung auf die Erdölfrage. Review of the Bulgarian Geological Society 10 (1), 1-34 (in Bulgarian, with German abstract).

Dabovski, H., Vasilev, E., Dimitrova, E. 2009. Mediterranean type Upper Cretaceous. In: Zagorchev, I., Dabovski, H., Nikolov, T. (Eds), Geology of Bulgaria. Part II, Mesozoic Geology. "Prof. Marin Drinov” Academic Publishing House, Sofia, 337-389 (in Bulgarian, with English abstract).

Dabovski, H., Zagorchev, I. 2009. Alpine tectonic subdivision of Bulgaria. In: Zagorchev, I., Dabovski, H., Nikolov, T. (Eds), Geology of Bulgaria. Part II, Mesozoic Geology. "Prof. Marin Drinov" Academic Publishing House, Sofia, 30-37 (in Bulgarian, with English abstract).

Dimitrov, H., Georgiev, G. 2005. Lithofacies analysis of the Kamchia basin (offshore zone) sedimentary sequences. Annual of the University of Mining and Geology "St Ivan Rilski” 48 (1), 47-52 (in Bulgarian, with English abstract).

Dimitrova, S. 1991. Report on the results from the prospecting drilling in Samotino area - west (hole R-85) conducted in 1985. Ministry of Energy, National Geological Fund, Report III-390, 114 pp. (in Bulgarian, unpublished).

Efremochkin, N. V., Yovchev, R. Y., Strepetov, V. P., Plotnikova, R. I., Bryukner, L., Dimovski, S., Agopyan, A., Parashkevova, V., Vavilova, M., Nikolova, M., Aleksiev, Y. 1974. Report on the results from the subsurface iodinebearing water prospecting in Dolna Kamchiya source with available reserve calculation (up to October 1, 1974). Ministry of Energy, National Geological Fund, Report V-223, 1202 pp. (in Russian, unpublished). 
Georgiev, G. 2012. Geology and hydrocarbon systems in the western Black Sea. Turkish Journal of Earth Sciences 21, 723-754.

Gočev, P. 1932. Geologische Beobachtungen an der Küste des Schwarzen Meers zwischen der Mündung der Kamčija und Kap Emine. Review of the Bulgarian Geological Society 4 (3), 200-213 (in Bulgarian, with German abstract).

Ivanov, M., Stoykova, K. 1994. Cretaceous/Tertiary boundary in the area of Bjala, eastern Bulgaria - biostratigraphical results. Geologica Balcanica 24 (6), 3-22.

Juranov, S. 1983. Planktonic foraminiferal zonation of the Paleocene and the Lower Eocene in part of East Balkan Mountains. Geologica Balcanica 13 (2), 59-73.

Juranov, S. 1984. Lithostratigraphy of the sedimentary rocks from the Senonian-Middle Eocene interval near the villages of Byala and Goritsa, Varna District. Annual of the Higher Institute of Mining and Geology 30 (2), 13-23 (in Bulgarian, with English abstract).

Juranov, S. 1991. Stratigraphy of the Upper Cretaceous series and the Paleogene system in the marine borehole sections at the village of Samotino. Review of the Bulgarian Geological Society 52 (3), 19-29 (in Bulgarian, with English abstract).

Juranov, S. 1993a. Byala Limestone-Marl Formation. In: Tenchov, Y. (Ed.), Glossary of the formal lithostratigraphic units in Bulgaria (1882-1992). Bulgarian Academy of Sciences Publishing House, Sofia, p. 32 (in Bulgarian).

Juranov, S. 1993b. Dolni Chiflik Member of the Avren Marl Formation. In: Tenchov, Y. (Ed.), Glossary of the formal lithostratigraphic units in Bulgaria (1882-1992). Bulgarian Academy of Sciences Publishing House, Sofia, p. 118 (in Bulgarian).

Juranov, S., Pimpirev, H. 1989. Lithostratigraphy of the Upper Cretaceous and Paleogene in the coastal part of East Stara Planina. Review of the Bulgarian Geological Society 50 (2), 1-18 (in Bulgarian, with English abstract).

Kânčev, I. 1995. Explanatory note to the geological map of Bulgaria on scale 1:100 000. Dolni Chiflik Map Sheet. Committee of Geology and Mineral Resources, Geology and Geophysics Ltd., Avers, Sofia, 113 pp. (in Bulgarian, with English abstract).

Kânčev, I., Gerčeva, Y. 1992. Geological map of Bulgaria on scale 1:100 000. Dolni Čiflik Map Sheet. Committee of Geology and Mineral Resources, Department of Geophysical Prospecting and Geological Mapping.

Kocheva, N., Manchev, T. 1995. Report on the oil and gas prospecting conducted in Novo Oryahovo area ( $R-81$ Novo Oryahovo hole), Ministry of Energy, National Geological Fund, Report III-466, 130 pp. (in Bulgarian, unpublished).

Monov, B. 1971. Report on the results from the structural drilling in Dolna Kamchiya area conducted in 1955-1961. Ministry of Energy, National Geological Fund, Report III-235, 576 pp. (in Bulgarian, unpublished).

Nikolova, M. 1968a. Report on the results from the structural drilling in Samotino area conducted in 1963-1965. Ministry of Energy, National Geological Fund, Report III-201, 155 pp. (in Bulgarian, unpublished).

Nikolova, M. 1968b. Report on the results derived from the deep prospecting drilling in Rudnik area conducted in 1962-1965. Ministry of Energy, National Geological Fund, Report III-208, 367 pp. (in Bulgarian, unpublished).

Nikolova, M. 1972. Report on the geological results from the prospecting hole $R$-54 in Samotino area conducted in 19681970. Ministry of Energy, National Geological Fund, Report III-241, 168 pp. (in Bulgarian, unpublished).

Nikolova, M. 1983. Report on the results of the profile drilling conducted in Bliznatsi area in 1981-1982. Ministry of
Energy, National Geological Fund, Report III-342, 328 pp. (in Bulgarian, unpublished).

Nikolova, M. 1985. Report on the results of the prospecting drilling conducted in Ravna Gora area ( $R$-76 hole). Ministry of Energy, National Geological Fund, Report III-339, 138 pp. (in Bulgarian, unpublished).

Nikolova, M. 1986. Report on the results of the prospecting drilling for non-anticline traps in the northern board of the Dolna Kamchiya Depression. Ministry of Energy, National Geological Fund, Report III-346, 446 pp. (in Bulgarian, unpublished).

Nikolova, M. 1992. Report on the results of the deep prospecting hole R-82 Krusha conducted in 1989. Ministry of Energy, National Geological Fund, Report III-391, 127 pp. (in Bulgarian, unpublished).

Petuhov, S., Palij, A., Melnik, L. 1952. Results on the oil and gas prospecting in Northeast Bulgaria, based on geological investigations conducted in 1949-1951. Ministry of Energy, National Geological Fund, Report III-97, 763 pp. (in Russian, unpublished).

Peybernès, B., Fondecave-Wallez, M.-J., Stoykova, K., Ciszak, R., Ivanov, M., Nikolov, T. 2003. Détermination de la limite Crétacé-Tertiaire en Bulgarie par les Foraminifères planctoniques. Geobios 37 (6), 755-769.

Pollak, A. 1933. Geologische Untersuchungen über das Endstück Ostbalkans. Abhandlungen der Mathematisch-Physischen Klasse der Sächsischen Akademie der Wissenschaften 41 (7), 1-60.

Popov, N., Kojumdjieva, E. 1987. The Miocene in Northeastern Bulgaria (lithostratigraphic subdivision and geological evolution). Review of the Bulgarian Geological Society 48 (3), 15-33 (in Bulgarian, with English abstract).

Preisinger, A., Aslanian, S., Stoykova, K., Grass, F., Mauritsch, H.J, Scholger, R. 1993a. Cretaceous/Tertiary boundary sections in the East Balkan area, Bulgaria. Geologica Balcanica 23 (5), 3-13.

Preisinger, A., Aslanian, S., Stoykova, K., Grass, F., Mauritsch, H.J, Scholger, R. 1993b. Cretaceous/Tertiary boundary sections on the coast of the Black Sea near Bjala (Bulgaria). Paleogeography, Palaeoclimatology, Paleoecology 104 (1-4), 219-228.

Shutskaya, E., Vaptsarova, A., Tanev, M., Goncharenko, B., Dencheva, D., Dianov, A., Jekova, K., Ignatova, V., Kehayova, M., Kulaksazov, G., Nikolov, T., Olferyev, A., Pozemova, A., Sapunov, I., Spasov, Ch., Stefanov, S., Tenchov, Y., Trifonova, E., Tronkov, D., Tsaneva, P., Tsankov, V., Yanev, S. 1972. Report on task I. Subdivision and correlation of borehole sections in North Bulgaria. Ministry of Energy, National Geological Fund, Report III-247, 959 pp. (in Russian, unpublished).

Sinnyovsky, D. 2001. Periodites from the Cretaceous- Tertiary boundary interval in several sections from East Bulgaria. Comptes rendus de l'Académie bulgare des Sciences 54 (4), 65-73.

Sinnyovsky, D. 2006. New data about the stratigraphic range of the Byala Formation near Byala town, Varna district. Annual of the University of Mining and Geology "St Ivan Rilski” 49 (1), 57-62 (in Bulgarian, with English abstract).

Sinnyovsky, D. 2007. Upper Cretaceous Calcareous Nannoplankton Biostratigraphy in Bulgaria. DSc Thesis, University of Mining and Geology "St Ivan Rilski”, Sofia, 167 pp. (in Bulgarian, unpublished).

Stefanov, Y. 2018. Illite/smectite diagenesis and thermal evolution of Lower Cretaceous-Paleogene successions in the Dolna Kamchiya Depression, Eastern Bulgaria. Geologica Balcanica 47 (1), 3-21. 
Stoykova, K., Ivanov, M. 2006a. A complete section of the Paleocene Series near Byala, East Bulgaria - nannofossil data. Proceedings of the Annual Scientific Conference “Geosciences 2006”, Bulgarian Geological Society, 83-84 (in Bulgarian, with English abstract).

Stoykova, K., Ivanov, M. 2006b. Middle and upper Paleocene nannofossil stratigraphy of Byala region (Black Sea coast, Bulgaria). Comptes rendus de l'Académie bulgare des Sciences 59 (11), 1167-1172.

Trifonova, E. 1960. Southsenonian foraminiferal species of the Maastrichtian near Biala Village, Varna District. Bulletin of the Institute of Geology “Strašimir Dimitrov" 8, 347-359 (in Bulgarian, with English abstract).

Valchev, B. 2017. Campanian planktonic foraminifera from the Byala Formation (Eastern Balkan). National Scientific Conference "Geosciences 2017", Short Communications, Bulgarian Geological Society, Sofia, 99-100.

Valchev B., Dimitrov, H. 2020. New data on the Paleogene lithostratigraphic units' distribution in the Avren Step south of Varna and Beloslav Lakes based on borehole data and seismic profiles' interpretation. Review of the Bulgarian Geological Society 81 (1), 55-67.

Valchev, B., Sachkov, D., Juranov, S. 2018a. 3D lithostratigraphic model of the Paleogene of the onshore part of the Moesian Platform (Northeast Bulgaria). Geologica Balcanica 47 (1), 23-36.

Valchev, B., Dimitrov, H., Sachkov, D., Juranov, S. 2018b. New data about the Dvoynitsa Formation distribution in the onshore part of the Dolna Kamchiya basin (Eastern Bulgaria) on the base of 3D lithological modeling. Comptes rendus de l'Académie bulgare des Sciences 71 (12), 1252-1256.

Valchev, B., Sachkov, D., Juranov, S. 2019. Paleogene lithostratigraphy in the Varna Plateau (Northeastern Bulgaria): a new view based on 3D modeling. Review of the Bulgarian Geological Society 80 (1), 41-53.

Vangelov, D., Sinnyovsky, D. 2011. New data about the Dvoynitsa Formation distribution, lithology and chronostratigraphic range, East Bulgaria. Annuaire de l'Université de Sofia, Faculté de Géologie et Géographie 49 (1), 43-70 (in Bulgarian, with English abstract).

Vavilova, M. 1990. Report on the results of the deep prospecting drilling in George Traykov area ( $R-1$ George Traykov hole), conducted in 1985-1987. Ministry of Energy, National Geological Fund, Report III-374, 435 pp. (in Bulgarian, unpublished).

Vavilova, M., Dimovski, S., Bryukner, L., Parashkevova, V., Nikolova, M. 1978. Report on the results of the deep drilling in Dolna Kamchiya area conducted in 1955-75. Ministry of Energy, National Geological Fund, Report III-294, 3171 pp. (in Bulgarian, unpublished).

Yolkichev, N. 1986. Lithostratigraphic units related to the Upper Cretaceous in the west and central Fore-Balkan. Review of the Bulgarian Geological Society 47 (3), 49-61 (in Bulgarian, with English abstract).

Zlatarski, G. 1907. Le Sénonien dans la Bulgarie orientale, au nord des Balkans et sa division en Emschérien et Aturien. Annuaire de l'Université de Sofia, Faculté Physico-mathématique 2, 31-51 (in Bulgarian, with French abstract). 